\title{
WORK ETHICS PROFILE OF VOCATIONAL COLLEGE STUDENTS IN INDONESIA
}

\author{
Yohana Ika Harnita Sari ${ }^{1 *}$, Endang Soelistiyowati ${ }^{1}$, Erlin Estiana Yuanti ${ }^{1}$ \\ ${ }^{1}$ Universitas Gadjah Mada \\ Jl. Persatuan, Blimbing Sari, Caturtunggal, Depok, Sleman, Yogyakarta 55281, Indonesia
}

\begin{abstract}
This study aims at describing the work ethics profile of Vocational College Students in Indonesia. Work ethics is an important indicator of human resources quality, and also an element of employability skills, that must be owned by students of Vocational College as working-age population. There are four main dimensions in work ethics: commitment, integrity, professional attitudes, and hard work. It is descriptive research on self-evaluation survey. It uses a Likert scale with five response options, ranging from 1 (never) to 5 (always). The respondents were determined using cluster sampling and convenience sampling. They are from four vocational colleges based on the three regions in Indonesia: College A (representing Western Indonesia colleges), College B and C (from Middle Indonesia), and College D (in Eastern Indonesia). This geographical perspective is used to get a profile of Vocational College students' work ethics regionally and nationally. The study concludes that there is no major difference among the self-evaluation results of work ethics in Western Indonesia, Middle Indonesia, and Eastern Indonesia (the mean scores of the four dimensions in four colleges range from 3.89 to 4.54). The study concludes that integrity is in the highest rank among other dimensions. The one that takes place in the second position is commitment, except the one in College C. It is consecutively followed by being professional (except College $C$ since its being professional is in the second place). The last is hard work. This profile signals positive support towards the demographic dividend for the development of the country.
\end{abstract}

Keywords: vocational college, work ethics, commitment, integrity, professional attitude, hard works

How to cite: Sari, Y., Soelistiyowati, E., \& Yuanti, E. (2020). Work ethics profile of vocational college students in Indonesia. Jurnal Pendidikan Vokasi, 10(3), 260-269. doi:https://doi.org/10.21831/jpv.v10i3.33809

*Corresponding Author: Yohana Ika Harnita Sari yohanaikahs@ugm.ac.id

Department of Languages, Arts and Culture Management, Vocational College, Universitas Gadjah Mada

Jl. Persatuan, Blimbing Sari, Caturtunggal, Depok, Sleman, Yogyakarta 55281, Indonesia 


\section{INTRODUCTION}

In 2030-2040, Indonesia is predicted to face demographic dividend (Ministry of National Development Planning/National Development Planning Agency, 2017). According to United Nations Population Fund (UNFPA) (2016),

"the demographic dividend is the economic growth potential that can result from shifts in a population's age structure, mainly when the share of the working-age population (15 to 64) is larger than the non-working-age share of the population (14 and younger, and 65 and older)."

In that period, the number productive-age population in Indonesia is foreseen to reach 64 percent of the predicted total number of Indonesian population, which is 297 million people (Ministry of National Development Planning/National Development Planning Agency, 2017). Joko Widodo, as the President of Indonesia in his speech in a DPR-RI and DPD-RI joint session to celebrate the $74^{\text {th }}$ Indonesian Independence Day, stated his optimism on the demographic dividend as a bonus leap for the advancement of the nation. Thus, all stakeholders focus on developing the quality of the human resource and on using many new methods related (Aivanni, 2019).

Thus, education plays an important role in preparing the human resources. Joko Widodo also mentioned that high education graduates should be competitive regionally and globally. Indonesian human resources should be competitive by possessing some characters, like hardworking, honest, collaborative, creative, having the ability to problem solving, and entrepreneurial. Besides, it is also important to become competitive by mastering the emerging skills to fulfill the emerging jobs and develop emerging business innovatively (Cabinet Secretariat of the Republic of Indonesia, 2019).

Since the students in high education belong to the working-age population, high education needs to enhance or maintain this competitiveness. It can be done by developing the work ethics of the high education students. This is in line with the statement of Wahyuna $(2013$, p. 30) that the inculcation of work characters or work ethics for vocational students is an important effort in producing students to be able to compete and succeed in their work. Work ethics education done explicitly and implicitly is believed to be able to prepare graduates to adapt more quickly to the working environment, and able to contribute positively and optimally for the company where they work.

According to Kasasbeh et al. (2014, p. 271), work ethics is a framework that regulates the behaviour and actions comprehensively related to company culture, values, and systems. In determining it, the stakeholders play a crucial role. Sinamo (2005) mentions that work ethics is a positive behaviour rooted in a basic belief together with commitment towards comprehensive work paradigm. Sinamo (2005) also states that if a person or group in an organization adheres to a good working paradigm, believes, and commits to the work paradigm, it will foster their good work attitude and behaviour. Through the aforementioned understandings, it is concluded that work ethics is attitude, behavior, and/or fundamental view based on the norm, which is believed by individuals, that encourage individuals to act as best as possible and achieve optimal results.

Work ethics has been a concern for many years because the work ethics is believed to contribute to one's performance and to make a person to be able to survive in the workforce (Boatwright \& Slate, 2002; Salahudin et al., 2016). The first study of the work ethics was done by Max Weber in 1904-1905 (Woehr et al., 2007), followed by Goldstein and Eichorn in 1961 with Protest Ethic Scale and Blood in 1969 with the Pro-Protestant Ethic Scale (Miller et al., 2002; Modrack, 2008), and Petty in 1993 and the collaboration between Petty and Hill in 1995, 1996, and 2005 also dominated journals related to the work ethics, which are about measuring instruments named Occupational Work Ethic Inventory (Park \& Hill, 2017). In addition, van Ness et al. (2010) also developed similar research to compare work ethics dimensions of graduates of three-year diploma program and undergraduate program and of the professionals. It is mentioned that there is no noticeable difference between the two groups.

This study focusses on the discussion of work ethics profile of the students in vocational colleges in Indonesia. It will be based on the preliminary study done by Soelistiyowati et al. (2017) through field observations and interviews. The dimensions included in the work ethics are commitment, integrity, professional attitudes, and hard work (Soelistiyowati et al., 2018). 
Commitment is a crucial part of the company. Without the strong commitment of any related member, the company will not develop (Johnson et al., 2010). Commitment is part of the work ethics and is divided into four main components (Meyer \& Herscovitch, 2001): strong desire to serve and being loyal to the company (membership focus), willingness to provide the best for the company (performance focus), willing to complete the task and responsibilities and exceed the target commitment, and willing to accept a greater responsibility (commitment to organizational change).

The next dimension of the work ethics is integrity. Monga (2016) describes integrity as a person's courage and consistency in doing something right, without hesitation, to meet the norms and standards in accordance with the prevailing norms. McFall (1987) mentions that integrity is a fairly complex concept that contains firm attitude to hold and apply the belief even in situations that may conflict with the belief. Corruption is an example of act that is opposed to integrity because in integrity there is consistent honesty over time. Honesty, as explained by Ahearne (2011), covers aspects such as saying according to facts, not distorting facts, and free from manipulation of messages both in speech and deed. In this study, integrity includes the ability to uphold the working principle, uphold truth in accordance with the code of ethics, and the ability to keep themselves free from corruption. A person with integrity will keep a mutual agreement, not violate work rules, maintain the company's good name, and not violate the profession code of ethics by not manipulating anything in its work for personal benefit and not accepting anything that is not his right.

The next dimension of work ethic in this research is a professional attitude. Some research mentions that the working world requires professional attitudes such as broad mastery over the areas of work, the ability and willingness of workers in providing excellent service, and being responsible of the work (Czerw \& Grabowski, 2015; Kleckner \& Marshall, 2014; Haserot, 2008). Someone is said to master the field of work well when he has the knowledge, experience, and intelligence in analyzing a problem. As for excellent service, it is interpreted as orientation in good, fair and high quality service to everyone and eager to do improvement. Then, the attitude of being responsible for his work includes the willingness of a person to finish his job and not manipulate anything in the work so as to reduce the quality of his work.

The fourth dimension of the work ethic in this study is hard work. When doing a focused group discussion (FGD) with the stakeholders, the stakeholders from some companies said that someone needs to work in any working condition, which means that someone is expected not to complain in any situation, nor is he easy to give up; but rather, he is to keep looking for solution of a problem. The hard work expected to be owned by workers in a company also includes the ability to make priorities so that the steps taken in completing the work can be more systematic, effective, and efficient (Soelistiyowati et al., 2017). That condition may occur if a person has strong motivation, confidence, positive mental attitude, hope of success, self-discipline, and persistence (Haddon, 1999; Hallowell, 2002). The last thing in hard work is a time discipline. The ability to set time is an important aspect in hard work (Sharma \& Rai, 2015). Sharma et al., (2017) state that effective time management makes one avoid the stress that arises, and can exceed the targets.

In addition, great work ethics as an element of employability skills has been recognized for long becomes essential part of vocational education and in other contexts. Accordingly, it is necessary to provide basis and environment for vocational education in which the students are able to display their work ethics and further improve their employability skills (Park \& Hill, 2017).

Arfandi (2013) in his research, describing the relevance of the graduate competencies (of Diploma 3 Civil Engineering) with the competencies needed in the world of work, reveals that the required graduate competencies for technical skills is $47.37 \%$ and the work skills (employability skills) is $58.21 \%$. It indicates that employability skills are valued higher than technical skills. The employability skills are more on the aspects of communication, initiative and courage, effort and teamwork ability, problem solving ability, positive thinking, ability to adapt, continuous learning, and working safely (Arfandi, 2013; Fitriyanto \& Pardjono, 2019).

Isaias and Issa (2014) state that the training process for developing professional attitudes in the workplace in every academic activity is needed. Besides, education that is work-oriented focusing on technical skills and employability skills mastery is meaningful to economic development sustainability in the $21^{\text {st }}$ century (Esposto \& Meagher, 2007 in Pusriawan \& Soenarto, 2019). Students also need ongoing feedback so they can see their achievements and to help them understand 
which parts need improvement. Thus, it is necessary to look for students' work ethics profile before they graduate. This research is expected to acquire students' work ethics profile, as an element of employability skills in Indonesia which can be used to determine strategic step in improving the quality of human resources to support the demographic dividend for the country's development.

\section{RESEARCH METHOD}

This study aims to describe the profile of work ethics of Indonesian vocational college students as part of working-age population in Indonesia. It uses a descriptive method using sample from some vocational colleges (under universities) or polytechnics in Indonesia consisting of one college from Sumatra Island (hereinafter referred to as College A), two colleges from Bali Island (hereinafter referred to as College B and C), and another one from Sulawesi Island (hereinafter referred to as College D). The sample for the survey was determined using the combination of cluster sampling and convenience sampling. Dividing population of vocational colleges or polytechnics students in Indonesia based on geographical perspective into three regions (Western, Middle, and Eastern Indonesia) reflects the cluster sampling done in this research. This study uses those clusters considering that the data can represent the profile of Indonesian students' work ethics regionally, in which the whole data can represent the national profile. Then, convenience sampling was done in determining the samples of each cluster. This method was used due to lack of resources to cover all universities or polytechnics in each cluster. In addition, 392 students were involved as the respondents for the survey, consisting of 109 College A students, 82 College B students, 100 College C students, and 101 College D students. They are majoring English language, accounting, informatics management, computer engineering, and statistics. They are projected to work in the related fields.

The survey was conducted using questionnaire. This instrument was to measure work ethics profile of those vocational colleges and/or polytechnics students which contains self-evaluation (44 questions) that are grouped into 13 indicators. Those indicators are classified into four dimensions; i.e. Commitment (four indicators), integrity (three indicators), being professional (three indicators), and hard work (three indicators). It uses Likert scale with following response options; 1 means never, 2 is rarely, 3 means sometimes, 4 is often, and 5 for always.

Self-evaluation, or called as self-rating or self-assessment, is utilized since it is more efficient than rating by others. Conelly and Ones (2010) (as cited in Kyllonen, 2013, p. 21) state that rating by others is "more accurate, less biased, and more predictive of future outcomes" compared to self-rating. However, difficulties in finding the capable person to rate, some excessive judgements, and different standards between raters can be weaknesses of rating by others. Therefore, this study employs simple self-rating scale (Likert scale) mentioned before. The research participants, i.e. the students in some vocational colleges/polytechnics, were asked to measure themselves in terms of their levels of commitment, integrity, being professional, and hard work.

Before it was conducted, some steps were done to check its validity and reliability. After the construct of the instrument was developed, it was empirically tested in some enterprises in all three regions in Indonesia and the results were discussed in an FGD. Then, it was revised and checked by a psychometrist and two psychologists using Delphi technique. They assessed the instrument and offered some feedbacks towards it. Afterwards, responses from 206 graduates of the Vocational College of Universitas Gadjah Mada were analysed for the next validity and reliability check.

The validity of the instrument construct was checked using Partial Least Square (PLS) with Smart PLS 2.0 M3. The result says that all 44 items are valid. Moreover, the score of the composite reliability is $>70$, thus all the dimensions are reliable. Subsequently, the data were collected using the questionnaire to 392 respondents. Descriptive statistics were engaged to analyze the data. Then, the data were presented descriptively.

\section{RESULTS AND DISCUSSION}

In this research, the work ethics profile of vocational college or polytechnic students in Indonesia are described in four different dimensions, namely commitment, integrity, being professional, and hard work. The data of the score of each dimension, the indicator of the dimensions, 
and the item of indicators from four different colleges are presented in Table 1, Table 2, Table 3 , and Table 4. Those scores are obtained from the mean of the response of the respondents in each college, and they are presented to provide the profile of the students.

Table 1. Commitment Dimension

\begin{tabular}{|c|c|c|c|c|c|c|c|c|c|c|c|c|c|}
\hline Indicator & Item & & $\mathbf{A}$ & & & B & & & C & & & D & \\
\hline $\begin{array}{l}\text { Strong desire to } \\
\text { serve and be loyal to } \\
\text { the company (mem- } \\
\text { bership focus) }\end{array}$ & $\begin{array}{l}1 \\
2 \\
3 \\
4\end{array}$ & 4.34 & 4.15 & $\begin{array}{l}4.27 \\
4.30 \\
3.58 \\
4.44\end{array}$ & 4.39 & 4.27 & $\begin{array}{l}4.41 \\
4.45 \\
3.65 \\
4.59\end{array}$ & 4.10 & 3.88 & $\begin{array}{l}3.93 \\
4.08 \\
3.45 \\
4.06\end{array}$ & 4.49 & 4.49 & $\begin{array}{l}4.50 \\
4.52 \\
4.15 \\
4.76\end{array}$ \\
\hline $\begin{array}{l}\text { Focus on Perfor- } \\
\text { mance, to provide } \\
\text { the best for the com- } \\
\text { pany (performance } \\
\text { focus) }\end{array}$ & $\begin{array}{l}5 \\
6 \\
7\end{array}$ & & 4.63 & $\begin{array}{l}4.70 \\
4.56 \\
4.62\end{array}$ & & 4.62 & $\begin{array}{l}4.70 \\
4.52 \\
4.63\end{array}$ & & 4.34 & $\begin{array}{l}4.45 \\
4.20 \\
4.37\end{array}$ & & 4.61 & $\begin{array}{l}4.75 \\
4.50 \\
4.58\end{array}$ \\
\hline $\begin{array}{l}\text { Focus on targets, and } \\
\text { diligently complete } \\
\text { the tasks and respon- } \\
\text { sibilities thoroughly } \\
\text { and beyond the target } \\
\text { (Goal Commitment) }\end{array}$ & $\begin{array}{c}8 \\
9 \\
10\end{array}$ & & 4.41 & $\begin{array}{l}4.63 \\
4.24 \\
4.37\end{array}$ & & 4.42 & $\begin{array}{l}4.60 \\
4.24 \\
4.43\end{array}$ & & 4.15 & $\begin{array}{l}4.40 \\
3.96 \\
4.09\end{array}$ & & 4.43 & $\begin{array}{l}4.68 \\
4.22 \\
4.38\end{array}$ \\
\hline $\begin{array}{l}\text { Willing to accept } \\
\text { greater responsibil- } \\
\text { ity, in accordance } \\
\text { with company policy } \\
\text { changes (Commit- } \\
\text { ment to Organiza- } \\
\text { tional Change) }\end{array}$ & $\begin{array}{l}11 \\
12 \\
13\end{array}$ & & 4.25 & $\begin{array}{l}4.28 \\
4.35 \\
4.14\end{array}$ & & 4.29 & $\begin{array}{l}4.39 \\
4.43 \\
4.05\end{array}$ & & 4.09 & $\begin{array}{l}4.14 \\
4.14 \\
3.99\end{array}$ & & 4.45 & $\begin{array}{l}4.55 \\
4.58 \\
4.21\end{array}$ \\
\hline
\end{tabular}

The mean scores of the commitment in those four colleges are between 4.10-4.49. It is based on the criteria adapted from Sudijono (2009, p. 175), 1.00-1.89 is 'irresponsible', 1.90-2.69 is 'not committed', 2.70-3.39 is 'fair', 3.40-4.19 is 'committed', and 4.20-5.00 is 'very committed'. It indicates that students are committed and very committed to their work. By being committed, workers can comply with the work standards, achieve the maximum results, and maintain the work and output quality (Hamidah, 2012, p. 360). The commitment is put in details into membership focus (four question items), performance focus (three question items), goal commitment (three question items), and commitment to organizational change (three question items). In College A, indicator that needs more attention is the first indicator, which is membership focus, particularly for question item number three. It is related to their commitment to keep working in the present company although they get some offer to work in other companies. Moreover, Colleges B and C face similar situation dealing with students' strong desire to serve and be loyal to the company. College D needs to maintain their commitment, since they are considered very committed in all commitment indicators.

Table 2. Integrity Dimension

\begin{tabular}{|c|c|c|c|c|c|c|c|c|c|c|c|c|c|}
\hline Indicator & Item & & $\mathbf{A}$ & & & B & & & C & & & D & \\
\hline $\begin{array}{l}\text { Firmly adhere to } \\
\text { work principle }\end{array}$ & $\begin{array}{l}14 \\
15 \\
16\end{array}$ & 4.52 & 4.47 & $\begin{array}{l}4.17 \\
4.58 \\
4.65\end{array}$ & 4.54 & 4.54 & $\begin{array}{l}4.32 \\
4.60 \\
4.71\end{array}$ & 4.32 & 4.26 & $\begin{array}{l}4.01 \\
4.34 \\
4.43\end{array}$ & 4.54 & 4.56 & $\begin{array}{l}4.34 \\
4.70 \\
4.63\end{array}$ \\
\hline $\begin{array}{l}\text { Uphold the truth in } \\
\text { accordance with the } \\
\text { code of ethics }\end{array}$ & $\begin{array}{l}17 \\
18 \\
19 \\
20\end{array}$ & & 4.48 & $\begin{array}{l}4.69 \\
4.65 \\
4.28 \\
4.30\end{array}$ & & 4.54 & $\begin{array}{l}4.70 \\
4.59 \\
4.45 \\
4.44\end{array}$ & & 4.33 & $\begin{array}{l}4.43 \\
4.46 \\
4.21 \\
4.22\end{array}$ & & 4.54 & $\begin{array}{l}4.64 \\
4.59 \\
4.47 \\
4.48\end{array}$ \\
\hline Anti-corruption & $\begin{array}{l}21 \\
22 \\
23\end{array}$ & & 4.61 & $\begin{array}{l}4.53 \\
4.71 \\
4.59\end{array}$ & & 4.53 & $\begin{array}{l}4.41 \\
4.61 \\
4.56\end{array}$ & & 4.36 & $\begin{array}{l}4.31 \\
4.43 \\
4.33\end{array}$ & & 4.52 & $\begin{array}{l}4.47 \\
4.57 \\
4.53\end{array}$ \\
\hline
\end{tabular}

Table 2 shows that all respondents from four colleges always show integrity seeing that the mean scores of this dimension from all colleges are above 4.20, in which the score range (rarely: 1.00-1.89; occasionally: 1.90-2.69; sometimes: 2.70-3.39; often: 3.40-4.19; and always: 4.20-5.00) 
is adapted from Sudijono (2009, p. 175). Always showing integrity is interpreted as students have moral quality. Huberts $(2018$, p. 3) said that "integrity is seen as the quality of acting in accordance or harmony with relevant moral values, norms, and rules". They firmly adhere to work principle by (14) obeying the work principles of the company in any such circumstances, (15) keeping a mutual agreement, and (16) feeling ashamed for violating work rules. They also defend the truth in line with the code of ethics. They (17) avoid doing actions that could defame company's good name, (18) will not do anything that violates the company's code of ethics, (19) are honest in speech and deed, and (20) keep the promise. Moreover, the students are anti-corruption. They (21) do not manufacture anything for personal benefit, (22) do not take what was not their right, and (23) refuse to accept something not right. However, College A and C students can maximize item number 14. By doing so, they can be more focused and productive since they always adhere the work principles.

Table 3. Being Professional Dimension

\begin{tabular}{|c|c|c|c|c|c|c|c|c|c|c|c|c|c|}
\hline Indicator & Item & & $\mathbf{A}$ & & & B & & & $\mathbf{C}$ & & & D & \\
\hline $\begin{array}{l}\text { Mastering the } \\
\text { field of work }\end{array}$ & $\begin{array}{l}24 \\
25 \\
26\end{array}$ & 4.33 & 4.10 & $\begin{array}{l}4.22 \\
4.17 \\
3.91\end{array}$ & 4.36 & 4.00 & $\begin{array}{l}4.04 \\
4.11 \\
3.84\end{array}$ & 4.15 & 3.90 & $\begin{array}{l}3.93 \\
4.01 \\
3.76\end{array}$ & 4.40 & 4.18 & $\begin{array}{l}4.20 \\
4.19 \\
4.16\end{array}$ \\
\hline $\begin{array}{l}\text { Providing excel- } \\
\text { lent service }\end{array}$ & $\begin{array}{l}27 \\
28 \\
29 \\
30\end{array}$ & & 4.44 & $\begin{array}{l}4.43 \\
4.50 \\
4.47 \\
4.34\end{array}$ & & 4.48 & $\begin{array}{l}4.40 \\
4.61 \\
4.62 \\
4.29\end{array}$ & & 4.23 & $\begin{array}{l}4.16 \\
4.21 \\
4.38 \\
4.16\end{array}$ & & 4.49 & $\begin{array}{l}4.57 \\
4.56 \\
4.53 \\
4.30\end{array}$ \\
\hline $\begin{array}{l}\text { Responsible for } \\
\text { work }\end{array}$ & $\begin{array}{l}31 \\
32 \\
33\end{array}$ & & 4.41 & $\begin{array}{l}4.57 \\
4.59 \\
4.08\end{array}$ & & 4.57 & $\begin{array}{l}4.67 \\
4.60 \\
4.43\end{array}$ & & 4.28 & $\begin{array}{l}4.34 \\
4.38 \\
4.13\end{array}$ & & 4.49 & $\begin{array}{l}4.63 \\
4.57 \\
4.26\end{array}$ \\
\hline
\end{tabular}

Referring to the score range (not professional: 1.00-1.89; less professional: 1.90-2.69; quite professional: 2.70-3.39; professional: 3.40-4.19; very professional: 4.20-5.00) which is adapted from Sudijono (2009, p. 175), the good result of the third dimension, being professional, exist in the four colleges. The mean scores of College A, B, and D are consecutively 4.33, 4.36, and 4.40. This means that the students are very professional, in terms of being responsible of their job, ability to give their best of their job, and the ability to give excellent service. Meanwhile the students of College $\mathrm{C}$ assess themselves as professional. In general, these students are able to master the field of their work, provide excellent service, and responsible for their work.

Among those ten assessment items, as shown in Table 3, there is a similarity that item number 26 gets the lowest score. This phenomenon happens to all colleges. The reasons could be that the students need to foster their skills further, over time, to be able to do the tasks well and smoothly. When they master particular skills, they will be called as competent in that particular field, and this usually takes time for the students to get the sense and habits. Professionalism is mostly measured with competency-based standard (Butter \& Hermanns, 2011, p. 32).

Table 4. Hard Work Dimension

\begin{tabular}{|c|c|c|c|c|c|c|c|c|c|c|c|c|c|}
\hline Indicator & Item & & A & & & B & & & $\mathbf{C}$ & & & D & \\
\hline $\begin{array}{l}\text { Eager to work } \\
\text { in any condition }\end{array}$ & $\begin{array}{l}34 \\
35 \\
36\end{array}$ & 3.89 & 3.90 & $\begin{array}{l}3.79 \\
4.24 \\
3.68\end{array}$ & 4.08 & 4.18 & $\begin{array}{l}4.12 \\
4.50 \\
3.93\end{array}$ & 3.93 & 3.92 & $\begin{array}{l}3.97 \\
4.19 \\
3.61\end{array}$ & 4.07 & 4.19 & $\begin{array}{l}4.01 \\
4.53 \\
4.04\end{array}$ \\
\hline $\begin{array}{l}\text { Able to make } \\
\text { priorities }\end{array}$ & $\begin{array}{l}37 \\
38 \\
39\end{array}$ & & 3.70 & $\begin{array}{l}3.72 \\
3.47 \\
3.91\end{array}$ & & 3.87 & $\begin{array}{l}3.88 \\
3.62 \\
4.12\end{array}$ & & 3.78 & $\begin{array}{l}3.74 \\
3.65 \\
3.96\end{array}$ & & 3.80 & $\begin{array}{l}3.71 \\
3.66 \\
4.01\end{array}$ \\
\hline Time Discipline & $\begin{array}{l}40 \\
41 \\
42 \\
43 \\
44\end{array}$ & & 4.00 & $\begin{array}{l}3.98 \\
3.70 \\
4.24 \\
4.05 \\
4.06\end{array}$ & & 4.15 & $\begin{array}{l}4.06 \\
3.99 \\
4.22 \\
4.28 \\
4.20\end{array}$ & & 4.03 & $\begin{array}{l}4.16 \\
3.83 \\
4.17 \\
4.02 \\
3.97\end{array}$ & & 4.15 & $\begin{array}{l}4.29 \\
3.90 \\
4.36 \\
4.07 \\
4.14\end{array}$ \\
\hline
\end{tabular}

Referring to Table 4, there are three indicators that explain hard work. First, the students should eager to work in any condition. Then, they need to be able to make priorities. The last is discipline. Students of College A and C reveal that they perform their hard work more through their 
time discipline and they need more effort in making priority. Meanwhile, College B and D share the similar pattern that their students, in term of hard work, are prominent in willing to work in any situation. On the other hand, they need more support to be able to make priority. From those result, ability to make priorities becomes the center of improvement effort. Overall, they often perform hard work dimension (rarely: 1.00-1.89; occasionally: 1.90-2.69; sometimes: 2.70-3.39; often: 3.40 - 4.19; and always: 4.20-5.00 - adapted from Sudijono (2009, p. 175)). The students' hard work is part of their success-oriented effort (Hamidah, 2012, p. 362).

The results of the aforementioned discussion are summarized in Figure 1. It is clear that integrity of the students in those four colleges is in the highest rank among other dimensions. The one that takes place in the second position is commitment, except the one in College C. It is consecutively followed by being professional (except College $\mathrm{C}$ since its being professional is in the second place). The last position is hard work. There is no significant difference among the four dimensions in four colleges which ranges from 3.89 to 4.54 .

\section{Work Ethics Profile}

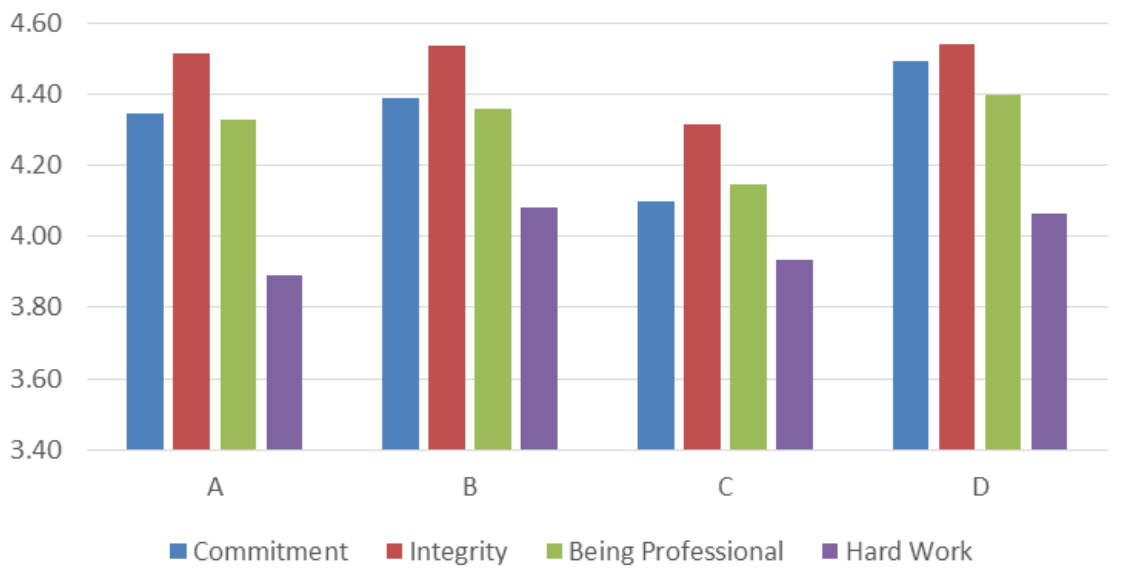

Figure 1. Profile of Work Ethics Dimensions in Each University

Figure 1 shows that students' work ethics profile in Western, Middle, and Eastern Indonesia reveal similar pattern. There is no inequality among the regional profiles. Thus, the aggregate results can be considered as national profile.

The profile is potential to reinforce economic growth in Indonesia. This statement is supported by some statements of the previous researchers. Inglehart (1997) and Inkeles and Smith (1974) (as cited in Weniger \& Bigley, 2019, p. 5494) say that work ethic can contribute to economic growth. They predict that work ethic is correlated with Gross Domestic Product (GDP) per capita and Gross National Income (GNI) per capita. In addition, the result of the latest research done by Weniger and Bigley $(2019$, p. 5495) is in line with the previous research saying that "work ethic has a relationship with economic growth", that is a longitudinal research conducted in the past three decades using World Values Survey administered in 80 societies around the world in three batches: 1990/1995, 1995/2000, and 2000/2005. Thus, this study reconfirms the previous research.

\section{CONCLUSION}

In general, students in College A, B, C, and also D, considered as working-age population in Indonesia, often and always perform work ethics in their daily life. The students are reported to show enthusiasm in working, and strive to perform best by giving excellent service. The students are said to have dignity to work with the best results and give their best to finish the task given ahead of time, with satisfactory results.

There is no major difference among the students' self-evaluation results of work ethics in Western, Middle, and Eastern Indonesia. They all show a certain level of expected work ethics. The profile supports Indonesian President's optimism of demographic dividend to develop the country. 
The implication is that the colleges in Indonesia need to continue training work ethics to the students, either explicitly or implicitly. In line with that, the vocational college students need to maintain their work ethics when they really come to the working world so that they perform well and paid well. Moreover, the authors or other researchers can use this information as the basic data to have future studies related to work ethics profile of workers in a particular sector or gap of work ethics profile between eras. It is strongly suggested to have more respondents to get more generalized results that represent the geographical clusters.

\section{ACKNOWLEDGMENTS}

The authors would like to thank the respondents of this study from the four colleges in Sumatra Island, Bali Island, and Sulawesi Island. The authors also thank the graduates of the Vocational College of Universitas Gadjah Mada as the respondents for validity and reliability check. Big thanks also go to the psychometrist and the psychologists who helped with checking the instrument using Delphi technique. This work was supported by the Kementerian Riset, Teknologi, dan Pendidikan Tinggi under a grant named Penelitian Terapan Unggulan Perguruan Tinggi in 2018.

\section{REFERENCES}

Ahearne, J. F. (2011). Ethics: Honesty. American Scientist, 99(2), 120-122. Retrieved from https:// www.jstor.org/stable/23019243

Aivanni, N. (2019, August 16). Presiden optimistis bonus demografi jadi lompatan kemajuan bangsa. Media Indonesia. Retrieved from https://mediaindonesia.com/read/detail/253668presiden-optimistis-bonus-demografi-jadi-lompatan-kemajuan-bangsa

Arfandi, A. (2013). Relevansi kompetensi lulusan diploma tiga teknik sipil di dunia kerja. Jurnal Pendidikan Vokasi, 3(3), pp. 283-292. https://doi.org/10.21831/jpv.v3i3.1843

Boatwright, J. R., \& Slate, J. R. (2002). Development of an instrument to assess work ethics. Journal of Industrial Teacher Education, 39(4), 1-23. Reetrieved from http://hdl.voced.edu. $\mathrm{au} / 10707 / 23156$

Butter, R., \& Hermanns, J. (2011). Impact of experienced professionalism on professional culture in probation. European Journal of Probation, 3(3), 31-42. https://doi.org/10.1177/20662203 1100300303

Cabinet Secretariat of the Republic of Indonesia. (2019, August 16). Pidato kenegaraan Presiden Joko Widodo dalam rangka HUT ke-74 proklamasi kemerdekaan Republik Indonesia, di depan sidang bersama Dewan Perwakilan Daerah Republik Indonesia dan Dewan Perwakilan Rakyat Republik Indonesia, 16 Agustus 2019, di Gedung MPR/DPR/DPD RI Senayan, Jakarta [Speech Transcript]. Retrieved from https://setkab.go.id/pidato-kenegaraan -presiden-joko-widodo-dalam-rangka-hut-ke-74-proklamasi-kemerdekaan-republik-indonesi a-di-depan-sidang-bersama-dewan-perwakilan-daerah-republik-indonesia/

Czerw, A., \& Grabowski, D. (2015). Work attitudes and work ethics as predictors of work engagement among Polish employees. Polish Psychological Bulletin, 46(4), 503-512. https:// doi.org/10.1515/ppb-2015-0057

Fitriyanto, M. N., \& Pardjono, P. (2019). Factors affecting the employability skills of vocational students majoring mechanical engineering. Jurnal Pendidikan Vokasi, 9(2), 132-140. http:// dx.doi.org/10.21831/jpv.v9i2.24420

Haddon, P. (1999). Mastering personal and interpersonal skills: Key techniques for effective decision making and personal success. Ashford Colour Press.

Hallowell, E. D. (2002). Teachers' perceptions about the Agency for Instructional Technology (AIT)'s applied communication program and career technical /business English courses on the development of entry-level and job-retention skills for the purpose of initial employment 
[Doctoral Dissertation]. Temple University, Philadelphia, PA. Retrieved from http://search. proquest.com/docview/305501432/FECE62732E834484PQ/33?accountid=13771

Hamidah, S. (2012). Profil soft skills mahasiswa Pendidikan Teknik Boga Fakultas Teknik Universitas Negeri Yogyakarta. Jurnal Pendidikan Vokasi, 2(2), 355-367. https://journal. uny.ac.id/index.php/jpv/article/download/1042/843

Haserot, P. W. (2008). Maintaining professionalism and harmony across the generations at work. Women Lawyers Journal, 93(3), 15-18. https://www.nawl.org/d/do/45

Huberts, L. W. J. C. (2018). Integrity: What it is and why it is important. Public Integrity, 20(Supp1), S18-S32. https://doi.org/10.1080/10999922.2018.1477404

Isaias, P. \& Issa, T. (2014). Promoting communication skills for information systems students in Australian and Portuguese higher education: Action research study. Education and Information Technologies, 18(3), 1-21. https://doi.org/10.1007/s10639-013-9257-9

Johnson, R. E., Chang, C. H., \& Liu, Q. Y. (2010). Commitment and motivation at work: The relevance of employee identity and regulatory focus. The Academy of Management Review, 35(2), 226-245. Retrieved from https://www.jstor.org/stable/25682410

Kasasbeh, E. A., Harada, Y., Bin Osman, A., \& Aldalayeen, B. O. (2014). The impact of business ethics in the competitive advantage (in the cellular communications companies operating in Jordan. European Scientific Journal, 10(10), 269-284. https://doi.org/10.19044/esj.2014.v10 $\mathrm{n} 10 \mathrm{p} \% 25 \mathrm{p}$

Kleckner, M. J., \& Marshall, C. R. (2014). Critical communication skills: Developing course competencies to meet workforce needs. Journal for Research in Business Education, 56(2), 59-81. Retrieved from https://search.proquest.com/docview/1764323553?pq-origsite=gschol ar\&fromopenview $=$ true

Kyllonen, P. C. (2013). Soft Skills for the Workplace. Change, 45(6), 16-23. https://doi.org/ 10.1080/00091383.2013.841516

McFall, L. (1987). Integrity. Ethics, 98(1), 5-20. Retrieved from https://www.jstor.org/stable/2381 289

Meyer, J. P., \& Herscovitch, L. (2001). Commitment in the workplace: Toward a general model. Human Resource Management Review, 11(3), 299-326. https://doi.org/10.1016/S1053-4822 (00)00053-X

Miller, M. J., Woehr, D. J., \& Hudspeth, N. (2002). The meaning and measurement of work ethic: Construction and initial validation of a multidimensional inventory. Journal of Vocational Behavior, 60(3), 451-489. https://doi.org/10.1006/jvbe.2001.1838

Ministry of National Development Planning/National Development Planning Agency. (2017, May 22). Bonus demografi 2030-2040: Strategi Indonesia terkait ketenagakerjaan dan pendidikan [Press Release]. Retrieved from https://www.bappenas.go.id/files/9215/0397/ 6050/Siaran_Pers_-_Peer_Learning_and_Knowledge_Sharing_Workshop.pdf

Modrack, S. (2008). The protestant work ethic revisited: A promising concept or an outdated idea?. WZB Discussion Paper, No. SP I 2008-101. Wissenschaftszentrum Berlin für Sozialforschung (WZB). Retrieved from http://hdl.handle.net/10419/43972

Monga, M. (2016). Meaning of integrity from the upper echelons' perspective. Journal of Developing Areas, 50(6), 333-340. https://doi.org/10.1353/jda.2016.0126

Park, H., \& Hill, R. B. (2017). Development and validation of a short form of the occupational work ethic inventory. Journal of Career and Technical Education, 32(1), 9-28. http://doi. org/10.21061/jcte.v32i1.1588 
Pusriawan, P. \& Soenarto, S. (2019). Employability skills of vocational students in Palu City for entering the work world. Jurnal Pendidikan Vokasi, 9(1), 33-42. http://dx.doi.org/10.21831/ jpv.v9i1.23351

Salahudin, S. N., Alwi, M. N. R., Baharuddin, S. S., \& Halimat, A. S. (2016). The relationship between work ethics and job performance. The European Proceedings of Social and Behavioural Sciences: BE-ci 2016: International Conference on Business and Economics, 465-471. http://dx.doi.org/10.15405/epsbs.2016.11.02.43

Sharma, B. R., \& Rai, S. (2015). A study to develop an instrument to measure work ethic. Global Business Review 16(2): 1-14. https://doi.org/10.1177/0972150914564417

Sharma, H., Mohan, A., \& Kumar, J. (2017). Time management. Grenze International Journal of Engineering and Technology (GIJET), 3(1), 20-23. Retrieved from http://thegrenze.com/ index.php?display=page $\&$ view=journalabstract $\&$ absid $=122 \& \mathrm{id}=8$

Sinamo, J. (2005). Delapan etos kerja profesional: Navigator anda menuju sukses. Grafika Mardi Yuana.

Soelistiyowati, E., Suwardo, S., Yuanti, E. Y., \& Sari, Y. I. H. (2017). Laporan akhir tahun penelitian unggulan perguruan tinggi (baru): Pengembangan model pembelajaran dan instrumen pengukuran kecakapan berelasi dan etos kerja. Unpublished manuscript.

Soelistiyowati, E., Yuanti, E. Y., \& Sari, Y. I. H. (2018). Laporan akhir tahun penelitian terapan unggulan perguruan tinggi (lanjutan): Pengembangan model pembelajaran dan instrumen pengukuran kecakapan berelasi dan etos kerja. Unpublished manuscript.

Sudijono, A. (2009). Pengantar statistik pendidikan. Rajawali Press.

United Nations Population Fund (UNFPA). (2016, May 5). Demographic dividend. Retrieved from https://www.unfpa.org/demographic-dividend?page $=7$

van Ness, R. K., Melinsky, K., Buff, C. L., \& Seifert, C. F. (2010). Work ethic: Do new employees mean New York Values? Journal of Managerial Issues, 22(1), 10-34. Retrieved from https:// www.jstor.org/stable/25822513

Wahyuna, G. F. (2013). Penanaman karakter kerja kelautan dan perikanan di SMKN 1 Sanden, Bantul Yogyakarta. Jurnal Pendidikan Vokasi, 3(1), 29-37. https://journal.uny.ac.id/index. php/jpv/article/view/1574/1301

Weniger, M., \& Bigley, J. (2019). Dependencies between work ethic and economic growth: A global perspective. The International Journal of Social Sciences and Humanities Invention 6(06), 5483-5499. https://doi.org/10.18535/ijsshi/v6i6.03

Woehr, D. J., Arciniega, L. M., \& Lim, D. H. (2007). Examining work ethic across populations: A comparison of the multidimensional work ethic profile across three diverse cultures. Educational and Psychological Measurement, 67(1), 154-168. https://doi.org/10.1177/00131 64406292036 